\title{
Joint Liability Groups (JLGs) - The Saviors of Urban Poor
}

\author{
Padma K.M.S., Venkata Subrahmanyam C.V., Dr. A. M. Suresh \\ Research Scholar,Department of Management Studies, Bharathiar University, Coimbatore - 641046 \\ Research Scholar,Department of Entrepreneurship Studies, Madurai Kamaraj University, Madurai - 625021 \\ Professor \& Director,Don Bosco Institute of Biosciences \& Management, Mysore Road, Bangalore - 560074
}

\begin{abstract}
According to the latest research done by the World Bank, India is home to almost one third of the world's poor (surviving on an equivalent of one dollar a day). Though many central government and state government poverty alleviation programs are currently active in India, microfinance plays a major contributor to financial inclusion. In the past few decades it has helped out remarkably in eradicating poverty. Reports show that people who have taken microfinance have been able to increase their income and hence the standard of living.

Microfinance is not just about giving micro credit to the poor rather it is an economic development tool whose objective is to assist poor to work their way out of poverty. It covers a wide range of services like credit, savings, insurance, remittance and also non-financial services like training, counseling etc. Microfinance institutions serve as a supplement to banks and in some sense a better one too.

The main two forms of group-based credit are - Self-Help Group (SHG) \& Joint Liability Group $(J L G)$.This paper discusses all about the Joint Liability Groups.

Key Words:JLG; Joint Liability Groups; Micro-Finance; MFI; Poverty Alleviation; Financial Services to the poor;
\end{abstract}

\section{Introduction:}

Poverty is one of the major problems in India. It is the root cause of many socio-economic problems including population explosion, unemployment, and child labor and rising graph of crimes. Poverty alleviation should be the main target of the nation so as to make it a prosperous and developed country. Thus, poverty elimination is a matter of fundamental importance. Poverty implies a condition in which a person finds him unable to maintain a living standard adequate for his physical and mental efficiency. He even fails to meet his basic requirements. Poverty is in fact a relative concept. It is very difficult to draw a demarcation line between affluence and poverty.

According to Adam Smith, "Man is rich or poor according to the degree in which he can afford to enjoy the necessaries, the conveniences and the amusements of human life."

Poor people can save and want to save, and when they do not save it is because of lack of opportunity rather than lack of capacity. During their lives there are many occasions when they need sums of cash greater than they have to hand, and the only reliable way of getting hold of such sums is by finding some way to build them from their savings. They need these lump sums to meet lifecycle needs, to cope with emergencies, and to grasp opportunities to acquire assets or develop businesses. The job of financial services for the poor, then, is to provide them with mechanisms to turn savings into lump sums for a wide variety of uses (and not just to run microenterprises). Good financial services for the poor are those that do this job in the safest, most convenient, most flexible and most affordable way.

Microfinance is one such financial service offered mainly with an aim to help such poor people who suffer from financial problems. The micro finance revolution, a recent product of development, ensures the availability of institutional credit and financial inclusion to the poor, who were so for excluded from the institutional credit system.

Microcredit has become a popular anti-poverty policy in the last decades. Now with more than 150 million borrowers, microcredit has undoubtedly increased access to formal financial services for the poor ${ }^{1}$.

\section{Microfinance - A Brief History}

Microfinance isthe provision of financial services to low-income clients or solidarity lending groups including consumers and the self-employed, who traditionally lack access to banking and related services. Microfinance sector has grown rapidly over the past few decades. Nobel Laureate Muhammad Yunus is

${ }^{1}$ Dr.K.Rajendran, 2012 
credited with laying the foundation of the modern MFIs with establishment of Grameen Bank, Bangladesh in 1976. Today it has evolved into a vibrant industry exhibiting a variety of business models.

Microfinance Institutions (MFIs) in India exist as NGOs (registered as societies or trusts), Section 25 of companies and Non-Banking Financial Companies (NBFCs). Commercial Banks, Regional Rural Banks (RRBs), cooperative societies and other large lenders have played an important role in providing refinance facility to MFIs. Banks have also leveraged the Self-Help Group (SHGs) channel to provide direct credit to group borrowers. With financial inclusion emerging as a major policy objective in the country, Microfinance has occupied center stage as a promising conduit for extending financial services to unbanked sections of population. At the same time, practices followed by certain lenders have subjected the sector to greater scrutiny and need for stricter regulation.

Salient features of Microfinance:

- Borrowers are from the low income group

- Loans are of small amount - micro loans

- Short duration loans

- Loans are offered without collaterals

- High frequency of repayment

- Loans are generally taken for income generation purpose

\section{MICROFINANCE IN INDIA}

Although the microfinance sector is having a healthy growth rate, there have been a number of concerns related to the sector, like grey areas in regulation, transparent pricing, low financial literacy etc. In addition to these concerns there are a few emerging concerns like cluster formation, insufficient funds, multiple lending and over-indebtedness which are arising because of the increasing competition among the MFIs. On a national level there has been a spate of actions taken to strengthen the regulation of MF sector including, enactment of microfinance regulation bill by the Government of Andhra Pradesh, implementation of sectorspecific regulation by Reserve Bank of India and most recently, release of Draft Microfinance Institutions (development and regulation) Bill, 2011 for comments. Based on the research work, a few major recommendations made in the report include field supervision of MFIs to check ground realities and the operational efficiency of such institutions. Offer incentives to MFIs for opening branches in unbanked villages, so as to increase rural penetration. Also MFIs be encouraged to offer complete range of products to their clients. Transparent pricing and technology implementation to maintain uniformity and efficiency are among the others which these institutions should adopt. Inability of MFIs in getting sufficient funds is a major hindrance in the microfinance growth and so these institutions should look for alternative sources of funds. Some of the alternative fund sources include outside equity investment, portfolio buyouts and securitization of loans which only a few large MFIs are currently availing.

\section{MICROFINANCE AND POVERTY}

In developing economies and particularly in rural areas, many activities that would be classified in the developed world as financial are not monetized: that is, money is not used to carry them out. This is often the case when people need the services money can provide but do not have dispensable funds required for those services, forcing them to revert to other means of acquiring them. The advocates of microcredit argue that microcredit can help to substantially reduce poverty ${ }^{2}$.

In his recent book, Stuart Rutherford cites several types of needs:

- Lifecycle Needs: such as weddings, funerals, childbirth, education, homebuilding, widowhood and old age.

- Personal Emergencies: such as sickness, injury, unemployment, theft, harassment or death.

- Disasters: such as fires, floods, cyclones and man-made events like war or bulldozing of dwellings.

- Investment Opportunities: expanding a business, buying land or equipment, improving housing, securing a job (which often requires paying a large bribe), etc.

Poor people find creative and often collaborative ways to meet these needs, primarily through creating and exchanging different forms of non-cash value. Common substitutes for cash vary from country to country but typically include livestock, grains, jewelry and precious metals.

Marguerite S Robinsonin 1980s demonstrated that "Microfinance could provide large-scale outreach profitably," and in the 1990s, "Microfinance began to develop as an industry". In the 2000s, the microfinance industry's objective is to satisfy the unmet demand on a much larger scale, and to play a role in reducing poverty. While much progress has been made in developing a viable, commercial microfinance sector in the last few decades, several issues remain that need to be addressed before the industry will be able to satisfy massive worldwide demand. The obstacles or challenges to building a sound commercial microfinance industry include:

2Littlefield et al 2003; Dunford 2006 
- Inappropriate donor subsidies

- Poor regulation and supervision of deposit-taking MFIs

- Few MFIs that meet the needs for savings, remittances or insurance

- $\quad$ Limited management capacity in MFIs

- Institutional inefficiencies

- Need for more dissemination and adoption of rural, agricultural microfinance methodologies

\section{MICROFINANCE INSTITUTIONS AND THE URBAN POOR}

According to the latest research done by the World Bank, India is home to almost one third of the world's poor (surviving on an equivalent of one dollar a day). Though many central government and state government poverty alleviation programs are currently active in India, microfinance plays a major contributor to financial inclusion. In the past few decades it has helped out remarkably in eradicating poverty. Reports show that people who have taken microfinance have been able to increase their income and hence the standard of living.

About half of the Indian population still doesn't have a savings bank account and they are deprived of all banking services. Poor also need financial services to fulfill their needs like consumption, building of assets and protection against risk. Microfinance is not just about giving micro credit to the poor rather it is an economic development tool whose objective is to assist poor to work their way out of poverty. It covers a wide range of services like credit, savings, insurance, remittance and also non-financial services like training, counseling etc. Microfinance institutions serve as a supplement to banks and in some sense a better one too. These institutions not only offer micro credit but they also provide other financial services like savings, insurance, remittance and non-financial services like individual counseling, training and support to start own business and the most importantly in a convenient way. The borrower receives all these services at her/his door step and in most cases with a repayment schedule of borrower's convenience. But all this comes at a cost and the interest rates charged by these institutions are higher than commercial banks and vary widely from 10 to 30 percent. Some claim that the interest rates charged by some of these institutions are very high while others feel that considering the cost of capital and the cost incurred in giving the service, the high interest rates are justified.

\section{GROUP-BASED CREDIT:}

Group- based credit or solidarity lending is a common practice in microfinance. Ratherthan lending to individuals, MFIs usually lend to small groups of people, who come together to borrow money and ensure timely repayment of the loan. This group-based approach has many advantages - more people tend to come forward and take a loan when they are part of a group. Also, peer pressure ensures that every member in the group repays. From the lending institution's point of view, lending to groups usually proves more cost-effective, since the cost associated with each loan is reduced by lending to groups. Also, usually there is no need for collateral if the loan is made to groups. The main two forms of group-based credit are:

\section{Self-Help Group (SHG)}

Self-Help Group refers to a group of 10-20 people who come from similar socio-economic backgrounds for various development programmes or to solve common problems. Such groups are recognized by the governments and banks and can open bank accounts in the name of the SHG. These groups tend to be autonomous and tend to involve themselves in various activities, including social causes. So if a group of fifteen women in a village would like to apply for a loan start a small enterprise selling bags and cushions, they would be considered an SHG. These SHGs, by way of enterprise tend to create more employment opportunities and inspire others to get involved in small enterprises as well.

\section{Joint Liability Group (JLG)}

A Joint Liability Group is usually a group of five to ten who come together to borrow from an MFI. The members in a JLG are also from similar socio-economic backgrounds and usually the same village. A JLG is different from SHGs in that the members share liability, or stand guarantee for each other. If any of the members default, the other members need to pool in money to repay the MFI. This ensures a greater effort on part of the members to ensure that everyone repays, thus ensuring resulting in better accountability and security for the MFI involved.

\section{JOINT LIABILITY GROUPS (JLGs):}

Each year the group members who want to borrow for seasonal production costs sign a contract in which they accept liability not only for their own individual loans, but also for the loans borrowed by other members of their group and hence the term 'joint-liability'. A basic requirement for joint-liability security for Bank loans is that the farmers concerned, form themselves into groups of people who know and trust each other. These groups may vary in size from a minimum of 4 to a maximum of 10 farmers depending on the need and circumstances. The loans are made by the bank to individual farmers or to the group collectively. The amounts 
borrowed by each person depend on his or her individual needs, subject to a maximum of certain prescribed amount in the policy (say Rs. 50,000) which can be borrowed with this form of security. The JLGs should necessarily comprise the farmers or entrepreneurs (undertaking production of the same crops or group of crops or undertaking non-farm activities to ensure cohesive functioning and facilitate procurement of inputs, processing, marketing, etc.)All the members of the JLG should be residing in the same village / compact area and not drawn from different / distant places.

Size of the JLG: The group should be formed preferably with 4 to 10 members (up to 20 members) to enable the group members to offer mutual guarantee.

Formation of JLGs: Banks may initially form JLGs by using their own staff wherever feasible. Banks may also engage business facilitators like NGOs and other individual rural volunteers to assist banks in promoting the concept and formation of groups. State Government Departments like Agriculture Department also could form JLGs of tenant farmers and small farmers not having clear land title. The JLGs of such eligible farmers can also serve as a conduit for technology transfer, facilitating common access to market information; for training and technology dissemination in activities like soil testing, training, health camps and assessing input requirements.

General features of JLG: A Joint Liability Group (JLG) is an informal group comprising of 4-10 individuals coming together for the purpose of availing bank loan on individual basis or through group mechanism against mutual guarantee. Generally, the members of a JLG would engage in a similar type of economic activity in the Agriculture and Allied Sector. The members would offer a joint undertaking to the bank that enables them to avail loans. JLG members are expected to provide support to each other in carrying out occupational and social activities.

Criteria for membership: Members should belong to similar socio-economic status, background and environment carrying out farming and Allied activities and who agree to function as a joint liability group. This way the groups would be homogeneous and organized by likeminded farmers/Individuals and develop mutual trust and respect. The members should be residing in the same village / area / neighborhood and should know and trust each other well enough to take up joint liability for group/ individual Loans. Members who have defaulted to any other formal financial Institution, in the past, are debarred from the Group Membership. More than one person from the same family should not be included in the same JLG.

Group Approach: All members of the JLG should be active enough to assume leadership of the group to ensure the activities of the JLG. The selection of an effective / able / active leader for the JLG is essential as this will ultimately benefit all the JLG members. The leader fosters a sense of unity, oversees and maintains discipline, shares information and facilitates repayments. For the bank, he is the focal point for group activities. The JLG should hold regular meetings which must be attended by all the members regularly to discuss issues of mutual interests. The principles of self - help and group strength need to be emphasized. Group cohesion has to be ensured. Adequate emphasis should be placed on the roles, expectations and functions of the group/members $\&$ the benefits of group dynamics. The JLG can easily serve as a conduit for technology transfer, facilitating common access to market information, for training and technology dissemination in activities like soil testing, training and assessing input requirements. The JLGs for specific nonfarm activity, e.g. production of handicrafts / other non-farm products may be federated at village/ block level for development of the product. The JLG in the clusters on their stabilization could come together in the form of cluster federation or producers' companies with a view to contributing the entire value chain and thereby achieving economies of scale in production and marketing of the product. The JLGs and evolving JLG structures are expected to build up empathy and understanding and create responsive lending mechanisms leading to greater interaction and interdependence between the members of JLGs

Credit Assessment: The JLG would prepare a credit plan for its individual members and an aggregate of that is submitted to the banks. Banks may evolve simple loan application for this purpose. The individual members of JLG would be eligible for bank loan after the bank verifies the individual members' credentials.

Purposes of credit: The finance to JLG is expected to be a flexible credit product addressing the credit requirements of its members including crop production, consumption, marketing and other productive purposes. Banks may consider cash credit, short-term loan or term loan depending upon the purpose of loan.

\section{JLG MODELS:}

Banks can finance JLG by adopting any of the two models.

\section{- Model A - Financing Individuals in the Group:}

Each member of the JLG should be provided an individual KCC. The financing branch could assess the credit requirement, based on the crop to be cultivated, available cultivable land / activity to be undertaken and the credit absorption capacity of the individual. All members would jointly execute a loan document, making each one jointly and severally liable for repayment of all loans taken by all individuals belonging to the group. The mutual agreement needs to ensure consensus among all 
members about the amount of individual debt liability that will be created including liability created out of the individual KCC. Any member opting out of group or joining the group will necessitate a new loan agreement, to be kept on record in the branch.

- $\quad$ Model B - Financing the Group:

The JLG functions, operationally, as one borrowing unit. The group would be eligible for accessing one loan, which could be combined credit requirements of all its members. The credit assessment of the group could be based on the micro enterprise / activity to be undertaken. All members would jointly execute the document and own the debt liability jointly and severally. The mutual agreement needs to ensure consensus among all members about the amount of individual debt liability that will be created. Any change in the composition of the group, will lead to a new document being registered by the branch.

\section{WHO CAN FORM JLGS?}

Business Facilitators, NGOs, Farmers Clubs, Farmers Associations, Panchayat Raj Institutions (PRIs), KrishiVikasKendras (KVKs), State Agriculture Universities (SAUs), Agriculture Technology Management Agency (ATMA), Bank branches, PACS, other cooperatives, Govt. Depts., Producer Associations , Artisan Guilds, Department of SMEs, Small Scale industries / Agro industries, Individuals, Input dealers, and Document writers (in cooperative banks),MFIs / MFOs, etc.

\section{SAVINGS:}

JLG members need to be encouraged to save regularly. Branches may open savings account by the JLG / individual members of the JLG to ensure regular savings and thrift habit amongst them. However, the quantum of loan to be given to the groups should be related to the credit needs of the enterprise and not to the quantum of savings.

\section{Conclusion}

Thus it is summed up from the above discussion that, JLG as a main form of microfinance plays a vital role as a savior for the urban poor in India. The main advantage is that it solves informational asymmetries by shifting the burden from the lender to the clients resulting in lower transaction costs for the institution (Ghatak and Guinnane, 1999), thus providing a way around the common problems of adverse selection (screening and sorting) and moral hazard (ex-ante and ex-post). The benefits availed through JLG helps the urban poor to solve their important problem of life i.e. fulfillment of financial needs.

\section{References:}

[1] Daley-Harris, S. (2009). "State of the Microcredit Summit Campaign Report 2009."

[2] Ghatak, M. and T. Guinnane (1999). "The Economics of Lending with Joint Liability: A Review of Theory and Practice", Journal of Development Economics 60: 195-228.

[3] Marguerite S Robinson, "The Microfinance Revolution”, 2001, p.54

[4] Stuart Rutherford, "The Poor and Their Money: An Essay about Financial Services for Poor People" 1999.

[5] Littlefield, E, J Morduch and S Hashemi (2003): 'Is Microfinance an Effective Strategy to Reach the Millennium Development Goals?', CGAP Focus Note 24, http://www.cgap.org

[6] Dunford, C (2006): Evidence of Microfinance's Contribution to Achieving the Millennium Development Goals: Freedom from Hunger,http://microfinancegateway.org/files/ 35795 file Evidence on MDGs Dunford.pdf

[7] Dr.K.Rajendran, "Micro Finance through Self He-lp Groups -A Survey of recent literature in India", International Journal of Marketing, Financial Services \& Management Research, Vol.1 Issue 12, December 2012, ISSN 22773622 , pp.110 -125

[8] Venkata SubrahmanyamC.V. and Dr. K. Ravichandran (2013) "The Role of Universities in Rural Development", IOSR Journal of Business and Management (IOSR-JBM) e-ISSN: 2278-487X.Volume 8, Issue 5 (Mar. - Apr. 2013), PP 23-27 www.iosrjournals.org $\mathrm{http} / /$ www.shgportal.com/index.php?shg=contents\&contentId=92\&ref=wia

$\begin{array}{ll}{[9]} & \text { http://www.shgportal.com/index.php?shg=cont } \\ {[10]} & \text { http://www.poverty-action.org/project/0034 }\end{array}$

[11] http://www.centre-for-microfinance.org/wpcontent/uploads/attachments/csy/2227/Incidence $\% 20$ of $\% 20$ Loan $\% 20$ Default $\% 20 \mathrm{in} \% 20 \mathrm{Group} \% 20 \mathrm{Lending} \% 20 \mathrm{Programme}$.pdf

[12] http://crawford.anu.edu.au/acde/events/adew-2013/papers/Shatragom,S_F1.pdf

[14] http://milaap.org/blog/microfinance-101-part-3-group-based-credit-shg-and-jlg/

[15] http://www.iitk.ac.in/ime/MBA IITK/avantgarde/? $\mathrm{p}=475$

[16] http://www.opportunity.org/what-is-microfinance/\#.UnoRFPmmiSo

[17] http://en.wikipedia.org/wiki/Microfinance

[18] http://www.microcreditsummit.org/uploads/socrs/SOCR2009_English.pdf 